\title{
THE FINAL DETERMINATION CLAUSE: DEFENSE TO EMPLOYEE SECTION 30I(a) SUITS
}

In LMRA section 301(a) suits by individual employees, the courts have primarily focused upon the presence or absence of contractual arbitration clauses in deciding whether or not to dispose of these actions on a motion for summary judgment. Frequently, however, labor contracts also include final determination clauses, the intended effect of which is to restrict the employee to the grievance procedure exclusively for resolution of his complaint. By analyzing open-end grievance procedures, which have no provision for arbitration but which often contain final determination clauses, this comment seeks to determine ultimate legal consequences of such clauses and to ascertain whether or not the results are consistent with federal labor policy.

A PRominent federal labor policy, enunciated both in statute and in Supreme Court decisions, encourages the private settlement of employee grievances through methods prescribed by the collective bargaining agreement.' This policy strengthens the representative role of labor organizations by requiring aggrieved employees to seek vindication of their contract rights through the union-controlled grievance machinery. ${ }^{2}$ The unions' exclusive power over employee grievances was, however, at least partially undermined by the Supreme Court's decision in Smith $v$. Evening

\footnotetext{
' See United Steelworkers v. Warrior \& Gulf Nav. Co., 363 U.S. 574, 582 (1960); Labor Management Relations Act (Taft-Hartley) $\$ 203(d), 29$ U.S.C. $\$ 173(d)$ (1964); Hays, The Future of Labor Arbitration. 74 YALE L.J. 1019, 1036 (1965).

: Where the union and the employer so provide in the collective bargaining agreement, an individual employee unquestionably has a right to have his grievance processed through the grievance machinery. See, e.g. Republic Steel Corp. v. Maddox, 379 U.S. 650 (1965). The National Labor Act, 29 U.S.C. $\$$ I59(a) (1964), provides that "any individual employee or group of employees shall have the right at any time to present grievances to their employer and to have such grievances adjusted, without intervention of the bargaining representative, as long as the adjustment is not inconsistent with the terms of the collective bargaining contract or agreement then in effect; Provided further. That the Bargaining representative
} 
Ven's Association ${ }^{3}$ which allowed individual employees' claims to be brought under section 30l(a) of the Labor Management Relations Act. ${ }^{+}$The effect of Evening News on private settlement procedures was initially speculative because the majority opinion, as Mr. Justice Black's dissent noted, "refrained from saying when, for what kinds of breach or under what circumstances an individual employee can bring a section 301 action ....". Subsequently, the courts have steadily cut down the practical efficacy of employee private suits under section 30l(a), especially in cases where the collective bargaining agreement has a clause that purports to make the employer-union resolution of grievances "final and binding" on all parties. ${ }^{6}$

In considering whether such a final determination clause can or should affect an employee's right to sue under section 301 (a), this comment surveys the major Supreme Court interpretations of section 30l(a) and analyzes those lower court decisions which have treated the issue. This inquiry will be made in the context of two kinds of grievance procedures: one which provides for impartial arbitration as the final step, and the other, known as an open-end procedure, ${ }^{7}$ having no arbitration clause. Consideration will also be given to the effect of an allegation of unfair representation upon the decisiveness of a final determination clause.

has been given opportunity to be present at such adjustment." This proviso has been interpreted as granting individual employees the right to process their own grievances. Si't. e.g., West Tex. Util. Co. v. NLRB, 206 F.2d 422 (D.C. Cir.), cert. denied, 346 U.S. 855 (1953). Nevertheless. other courts have held that the proviso merely gives the employer the freedom to consider grievances presented by an individual employee without conferring upon the employee a substantive right to compel the employer to process his grievance. F.g.. BlackClawson Co. v. International Ass'n of Machinists, 313 F.2d 179 (2d Cir. 196I). Se' generall! Wyle, Labor Arbitration and the Concept of Lixclusive Represemation. 7 B.C. IVD. \& COM. L. REV. 783 (1966).

371 U.S. 195 (1962). See notes $23 \& \geq 4 \mathrm{in} / \mathrm{ra}$ and accompanying text.

'Labor Management Relations Act (Taft-Hartley) $\$ 301$ (a), 29 U.S.C. \$ 185(a) (1964), Section 301 (a) is entitled "Suits by and against Labor Organizations." For a quotation of the language of $\$ 301$ (a) of the LMRA, see text accompanying note $18 \mathrm{in} / \mathrm{ra}$.

371 U.S. at 204; se' Aughenbaugh v. North Am. Refractories Co.. 426 Pa. 364. 231 A.2d 173 (1967).

- Sec. e.g.. Humphrey v. Moore, 375 U.S. 335 (1964); Haynes v. United States Pipe \& Foundry Co., 362 F.2d 414 (5th Cir. 1966); Hildreth v. Union News Co., 3I5 F.2d 548 (6th (ir.), corl. denied. 375 U.S. 826 (1963).

Sece e.s. Haynes $v$ United States Pipe \& Foundry (0.. 362 1.2d 414 (5th Cir. 1966): International Bhd. of Tel. Workers v. New England Tel. \& Tel. Co., 240 F. Supp. 426 (D. Mass. 1965): Alarcon v. Fabricon Prods., 5 Mich. App. 25, 145 N.W.2d 816 (1966). 


\section{Grievance Machinery}

As a means of settling employee grievances expeditiously and of discouraging specious claims, employers and unions frequently incorporate grievance procedures into their collective bargaining agreements. Under the terms of these agreements, when a complaint arises the individual employee must first attempt to utilize the grievance machinery before bringing a law suit against his employer for breach of the contract. ${ }^{8}$ A typical grievance procedure consists of three to five steps. ${ }^{9}$ First, the employee or his union representative presents the grievance to the company's department foreman and division superintendent. The grievance committees of the union and employer then meet. Unless the grievance is "washed out" or remedied at one of these early stages, it is pressed through the remaining steps specified in the collective bargaining agreement, the final stage of which generally provides either for impartial arbitration of the grievance or for serving a strike notice on the employer. It has been reported that in collective bargaining agreements which cover one thousand or more employees, 94 percent of grievance procedures now provide forarbitration as the final step. ${ }^{10}$ Despite this statistic, open-end grievance procedure remains very important in smaller-scale labor

"Republic Steel Corp. v. Maddox, 379 U.S. 650 (1965). See notes 34-37 infra and accompanying text. While the collective bargaining agreement in Maddox provided for arbitration as the final step of the grievance procedure, the fifth Circuit has interpreted the Maddox holding as binding an employee to the contractual remedies even when they do not include arbitration. See Haynes v. United States Pipe \& Foundry Co., 362 F.2d 414, 417 (5th Cir. 1966); notes 59-64 infra and accompanying text.

- In Vaca v. Sipes, 386 U.S. 171 (1967), the collective bargaining agreement created a fivestep grievance procedure, with the fifth step being the referral ol the grievance to a specified arbitrator. /d. at 175 n.3. The contract involved in Haynes v. United States Pipe \& Foundry Co., 362 F.2d 414 (5th (ir. 1966), provided for a grievance procedure whose fifth and final step required a letter from the union to the plant manager to the effect that the union intended to strike in protest of the plant manager's denial of the grievance in the fourth step. Id. at 415-16. Republic Steel Corp. v. Maddox, 379 U.S. 650 (1965), interpreted a grievance procedure having four steps, the last of which was a provision for arbitration. Id. at 660-62 n.2. See generally. Rosen. The Individual Worker in Grievance Arbitration: Still .Another Look at the Problem. 24 MD. L. Rev. 233, 244-5I (1964).

i" U.S. Blikfau of Labor Statistics, Dep't of Labor, Bull. No. 1425-6, Major

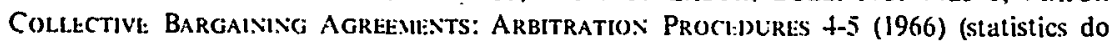
not include railroad, airline and government-employee collective bargaining agreements): see A. Con \& D. Bok. (asi's ANis Mati:RIAl.s on Labor Law 516 (6th ed. 1965): Jay, Irbitration and the ficederal common l.aw of Collective Bargaining .Igreenemts. 37 N.Y.U.L. REV. 448,452, n.18 (1962). 
contracts, and a few sources indicate that it may be of increasing importance even in large scale agreements."

As an adjunct of the grievance machinery provisions, the collective bargaining agreement may include a final determination clause making any settlement between the union and the employer at any stage of the grievance proceedings binding upon the aggrieved employee, the union; and the employer. ${ }^{12}$ If such a clause is conclusive of the employee's rights, it may deprive him of an opportunity to receive an impartial determination of the merits of his grievance, particularly if the union's interests could be adversely affected by processing the grievance completely through the grievance machinery. ${ }^{13}$ This potential unfairness to the employee, the probability of which is increased when the open-end grievance procedure is utilized, lies at the root of the conflict over the employee's right to sue under section 301 (a).

\section{SECTION 203(d) OF THE LMRA}

Federal encouragement of the grievance-procedure method of settling employee disputes arising under a labor contract is manifested clearly by the deference paid to it by both Congress and the Supreme Court. Congressional preference for the collective bargaining solution to employee grievances is palpably expressed in section 203(d) of the Taft-Hartley Act:

Final adjustment by a method agreed upon by the parties is declared to be the desirable method for settlement of grievance disputes arising over the application or interpretation of an existing collective bargaining agreement. ${ }^{14}$

"A recent report indicates that "there appears to have been a leveling-off in the number of new cases [of grievance arbitration]. The American Arbitration Association says its 1966 caseload fell from 1965, the second such year-to-year decline in the past four years. A number of companies say they have begun to rely less on arbitration, and a few have abandoned it almost completely." Green, Settling Differences. Wall Street Journal. July I3, 1967, at 1, col. 6; see Repas, Grievance Procedures Without Arbitration, 20 IND. \& LAB. REL. REv. 381 (1967).

"See. e.g.. Haynes v. United States Pipe \& Foundry Co., 362 F.2d 414, 416 (5th Cir. 1966). The collective bargaining agreement involved in Rothlein v. Armour \& Co., 391 F.2d 574 (3d Cir. 1968), contained a typical final determination clause which stated that "when a settlement is arrived at, at any stage of this [grievancel procedure, such decision shall be final and binding on all parties." Id. at 577 n.7. See generally Comment, Section 30/(a) and the Eniployee: An Illusory Remedy, 35 Ford. L. REv. 517, 518-28 (1967).

${ }^{13}$ See notes 78-82 infra and accompanying text.

" 29 U.S.C. \& 173(d) (1964). 
The Supreme Court has liberally interpreted section 203(d) as requiring that the means of grievance settlement provided in the collective bargaining agreement be given "full play" by the courts. ${ }^{\text {s }}$ Without further explaining the import of the term "full play," the courts continually have sought to effectuate the policy of section $203(d)^{16}$ by limiting the remedies of the individual employee to those agreed upon.

\section{Section 301 (a) and Federal Labor Law}

The section 203(d) policy approving private-dispute settlement procedures is especially germane to an analysis of LMRA section 301 (a), ${ }^{17}$ which provides:

Suits for violation of contracts between an employer and a labor organization representing employees in an industry affecting commerce.... or between any such labor organizations, may be brought in any district court of the United States having jurisdiction of the parties, without respect to the amount in controversy or without regard to the citizenship of the parties. ${ }^{18}$

Section 301 (a) does not specifically authorize the federal courts to entertain suits alleging employee grievances; nor does it specify who can institute actions under it. These questions were left for the courts to resolve in the hope that rules of decision consistent with the policy of the national labor laws would develop. ${ }^{19}$

Looking only at the principal purpose behind section 301(a)-to provide a suitable forum in which labor agreements could be

1s United Steelworkers v. American Mfg. Co., 363 U.S. 564, 566 (1960).

16 E.g. Vaca v. Sipes, 386 U.S. 171 (1967); United Steelworkers v. American Mfg. Co., 363 U.S. 564 (1960); Dallas Typographical Union, Local 173 v. A.H. Belo Corp., 372 F.2d 577 (5th Cir. 1967); United Furniture Workers v. Fort Smith Couch \& Bedding Co., 214 F. Supp. 164 (IV.D. Ark. 1963).

"See General Drivers, Local 89 v. Riss \& Co., 372 U.S. 517 (1963) (per curiam), in which the Court held that a district court had jurisdiction under section 301 (a) to enforce an award rendered through the employment of grievance machinery established by the collective bargaining agreement, even though the award may not have been a produet of arbitration.

1" 29 U.S.C. § 185(a) (1964).

19 Section $30 /$ (a) does not divest the state courts of jurisdiction in actions brought thereunder. Charles Dowd Box Co. v. Courtney, 368 U.S. 502 (1962). Nevertheless, the state courts must follow and apply federal law in all section 301 (a) suits. Local 174. Teamsters Union v. Lucas Flour Co., 369 U.S. 95 (1962); Textile Workers Union v. Lincoln Mills, 353 U.S. 448 (1957). But see UAW v. Hoosier Cardinal Corp., 383 U.S. 696 (1966) (state statute of limitations applied in a section $30 \mathrm{I}$ action).

"Senate Comi. on labor and Public Welfare, The Proposed federal Labor Relations ACt of 1947, S. Rep. No. 105, 80th Cong., 1st Sess. 15-16 (1947). 
enforced ${ }^{20}$ it is difficult to see how this statute could collide with the closely related policy of section 203(d). Indeed, in the first major judicial construction of section 301(a), Textile Workers Union v. Lincoln Mills, ${ }^{21}$ the Supreme Court ordered an employer to abide by his promise to arbitrate employee grievances and thus effectuated enforcement of the section 203(d) policy of encouraging private-settlement processes. ${ }^{22}$

The potential for conflict between the operative effects of section 301(a) and the policy of section 203(d) resulted from the Supreme Court's holding in Sinith v. Evening News Association. ${ }^{23}$ By allowing an individual employee to sue his employer for breach of the collective bargaining agreement, ${ }^{24}$ Evening News raised the

$\because 353$ U.S. 448 (1957), noted in 57 COLUM. L. Rev. 1123 (1957), 43 CoRnell L.Q. 503 (1958) and II VAND. L. Rev. 243 (1957); see Bickel \& Wellington, Legislative Purpose and the Judicial Process: The Lincoln Mills Case, 71 HaRv. L. Rev. I (1957); Bunn, Lincoln Mills and the Jurisdiction to Enforce Collective Bargaining Agreements. 43 VA. L. Rev. 1247 (1957); Feinsinger, Enforcement of Labor. Agreements-A New Era in Collective Bargaining, $43 \mathrm{~V}_{\mathrm{A}}$. L. REv. 1261 (1957).

": The employers in Lincoin Mills had refused to submit an employee grievance to arbitration, which was established by the contract as the ultimate means of settling disputes. 353 U.S. at 449. Asserting that the legislative history of the Taft-Hartley Act demonstrated that Congress sought to make coilective bargaining agreements equally binding upon and enforceable against all parties to them, the Lincoln Mills Court held that section 301 authorized federal district courts to compel specific performance of the employer's promise to arbitrate. 353 U.S. at 456 . Writing for the majority, Mr. Justice Douglas prefaced his discussion of the legislative history by noting: "The legislative history of $\$ 301$ is somewhat cloudy and confusing. But there are a few shafts of light that illuminate our problem." $/ d$. at 452: see Feinsinger, supra note 21, at 1267-72. For the legislative history of section 301, see the appendix to Textile Workers Union v. Lincoln Mills. 353 U.S. at 485.

${ }^{33} 371$ U.S. 195 (1962), noted in 4 B.C. IND. \& Com. L. Rev. 766 (1963), II U.C.L.A.L. REV. 438 (1964) and 16 VAND. L. ReV. 1252 (1963).

${ }^{3}$ A nother important holding of the Supreme Court in Evening New's was that even though the facts alleged arguably constituted an unfair labor practice, state court jurisdiction was not preempted. 371 U.S. at 197-201. The Court noted that, "[a]ccording to this view [of respondent company], suits by employees for breach of a collective bargaining contract would not arise under $\S 301$ and would be governed by state law, if not preempted by Garmon [San Diego Building Trades Council v. Garmon, 359 U.S. 236 (1959)], as this one would be, whereas a sujt by a union for the same breach of the same contract would be a $\S 301$ suit ruled by federal law. Neither the language and structure of $\$ 301$ nor its legislative history requires or persuasively supports this restrictive interpretation, which would frustrate rather than serve the congressional policy expressed in that section." $\mid d$. at 200.

The Court earlier had ruled in Dowd Box Co. v. Courtney. 368 U.S. 502 (1962), that " 301 (a) simply gives the federal district courts jurisdiction over suits for violation of certain specified types of contracts. The statute does not state nor even suggest that such jurisdiction shall be exclusive." Id. at 506; see Feldesman, Section 301 and the National 
possibility that employees would ignore the grievance machinery altogether and go directly to the courts to settle their claims. While the correlative right to sue their union for breach of the duty of fair representation provided employees with protection from union abuses of the grievance machinery, ${ }^{25}$ the possibility remained that a grievant might undermine the collective settlement processes by refusing to allow his union a reasonable chance to settle his case. As a practical matter, if employee grievances were sure to get a thorough second look in the courts, the private-settlement mechanisms would be much less important, and might atrophy entirely.

Apparently realizing that full expansion of the individual's right to sue his employer or bargaining representative would subvert the congressional policy of section 203(d), the Supreme Court undertook to accommodate sections 301(a) and 203(d) in Republic Steel Corp. v. Maddox. ${ }^{26}$ in an opinion that stressed the federal policy of fostering private settlement of labor disputes, ${ }^{27}$ the Court dismissed the complaint of an employee because he brought the court action without first seeking redress through the available grievance machinery. ${ }^{28}$ The holding in Maddox promulgated a

Labor Relations Act. 30 TENN. L. Rev. 16 (1962); Sovern, Section 301 and the Primary' Jurisdiction of the NLRB, 76 HARV. L. REV. 529 (1963).

${ }^{2 s}$ Humphrey v. Moore, 375 U.S. 335 (1964), noted in 5 B.C. IND. \& CoM. L. Rev. 848 (1964), 12 U.C.L.A.L. Rev. 1238 (1965) and 17 VAND. L. ReV. 1328 (1964). The employee's individual right to sue under section 301 (a) was enlarged in Humphrey y. Moore which held that in some circumstances an employee may sue his bargaining representative under section 301 (a) by alleging that the union breached the contract by violating its duty of fair representation. The Court stated: "Although there are differing views on whether a violation of the duty of fair representation is an unfair labor practice . . . , it is not necessary for us to resolve that difference here. Even if it is, or arguably may be an unfair labor practice, the complaint here alleged that Moore's discharge would violate the contract and was therefore within the cognizance of federal . . courts. . ." 375 U.S. at 344 . In concurring, Mr. Justice Goldberg disagreed with the majority's rationale, contending that "such a claim of breach of the union's duty of fair representation cannot properly be treated as a claim of breach of the collective bargaining contract supporting an action under $\$ 301$ (a)." $/ d$. at 355.

${ }^{26} 379$ U.S. 650 (1965), noted in 25 LA. L. REv. 949 (1965); see Zile, The Componential Structure of Labor-Management Contractual Relationships: Republic Steel Corp. v. Maddox and Humphrey v. Moore. 43 U. DET. L.J. 321 (1966).

" 379 U.S. at 653.

"By concluding that "unless the contract provides otherwise, there can be no doubt that the employee must afford the union the opportunity to act on his behalf," id. at 653 , the majority in Maddox provoked a vigorous dissent by Mr. Justice Black. He asserted: "1 cannot and do not believe any law Congress has passed provides that when a man , becomes a 
general rule that employees had to attempt to exhaust the grievance machinery established in the collective bargaining agreement before going to court. ${ }^{29}$

The Supreme Court's latest effort to construe section 301(a), Vaca $v$. Sipes, ${ }^{30}$ represents an extension of previously enunciated principles. The union in Vaca refused to submit the employee's grievance to arbitration, which was the fifth and final step in the grievance procedure. The grievant sued his union, alleging in his 301 (a) action a breach of the union's duty of fair representation. The Court reversed the judgment of the Missouri Supreme Court because, in determining that the union had not breached its duty, that court failed to apply the proper standard, which is whether the "union's conduct toward a member of the collective bargaining unit is arbitrary, discriminatory, or in bad faith." 31 By reviewing the facts of the state court decision, the court reaffirmed that state court jurisdiction over a breach of contract action is not preempted by the National Labor Relations Act, even though the facts alleged constitute a union unfair labor practice. ${ }^{32}$

member of a labor union in this country he thereby has somehow surrendered his own freedom and liberty to conduct his own lawsuit for wages." Id. at 670. Several commentators support the position of Mr. Justice Black. See, e.g., Blumrosen, WorkerUnion Relationship, 61 Mich. L. REv. 1435 (1963); Summers, Individual Rights in Collective Agreements and Arbitration, 37 N.Y.U.L. REv. 362 (1962); Tuttle, Federal Protection of Individual Rights Under Labor Contracts, 73 YALE L.J. 1215 (1964): Wolk, The Decline of Individual Rights, 16 LAB. L.J. 266 (1965). But see notes 108-10 infra and authorities cited therein.

${ }^{29}$ The narrow holding emphasized that "individual employees wishing to assert contract grievances must attempt use of the contract grievance procedure agreed upon by employer and union as the mode of redress." 379 U.S. at 652 (emphasis by the Court). However, in dictum the Maddox Court stressed that "if the union refuses to press or only perfunctorily presses the individual's claim, differences may arise as to the forms of redress then available." Id. 379 U.S. at 652 (emphasis added).

${ }^{30} 386$ U.S. 171 (1967), noted in 14 U.C.L.A.L. REv. 1351 (1967), 13 WAYNE L. Rev. 602 (1967) and 77 YALE L.J. 559 (1968).

3386 U.S. at 190; see id. at 189-98.

32 The narrow holding was that the jurisdiction of the courts is not preempted in this instance by the NLRB's exclusive jurisdiction over unfair labor practices merely because the employee in his section 301 action alleges that the union breached its statutory duty of fair representation, which the Board considers to be an unfair labor practice. $/ d$. at 177-88. This holding represents an exception to the broad preemption doctrine promulgated by the Court in San Diego Building Trades Council v. Garmon, 359 U.S. 236 (1959). In addition to this holding, the Vaca Court presented several reasons for permitting state courts to exercise jurisdiction over such cases rather than placing exclusive jurisdiction in the NLRB. First, the need for avoiding possible conflicts in the substantive law, which justifies giving one body 
More important for its analysis of the interaction of sections 301 (a) and 203(d) is the strong dictum in Vaca which sets forth the prerequisites to section 301(a) relief by an aggrieved employee. The discussion in $\mathrm{Vaca}$ is perhaps best understood as an extension of the exhaustion of remedies rule established in Republic Steel Corp. v. Maddox. ${ }^{33}$ Whereas Maddox required an employee to attempt to exhaust the grievance machinery before suing under section 301(a), the Vaca Court apparently holds that an excusable failure to exhaust contractual remedies must be traceable to an unlawful act by the employee's union. Thus where an employee's claim has not in fact been processed through all steps of the grievance procedure, the employer's motion for summary judgment will be granted unless the employee can show a breach of the duty of fair representation by his union. ${ }^{34}$ This result narrows the accessability of section 30l(a) relief, and thus enhances the role of privatesettlement procedures as advocated by the policy behind section 203(d). ${ }^{35}$ The exhaustion rule reflects the effort of the Court to balance the congressional policy of section 203(d) against the judicial protection afforded employees by section 301 (a). However, within this framework, the Supreme Court has not yet determined whether there is or should be a distinction between procedures with an arbitration provision and open-end procedures having no arbitration clause. Nor has the Court explicitly resolved the issue of the effect to be accorded a final determination clause when asserted by either the employer or the union in defending against an employee's section 301 (a) action.

exclusive jurisdiction, was not present because the Board itself, in disposing of unfair representation allegations, employs doctrines developed and applied by the courts. 386 U.S. at 180-81. Moreover, such suits entail the assessment of substantive policies and postures assumed in bargaining negotiations, a task which courts can perform as satisfactorily as the Board. 386 U.S. at 181. Furthermore, the NLRB's General Counsel, exercising his unreviewable discretion, often will refuse to file complaints with the Board against unions on behalf of individual employees, thereby limiting the availability of Board consideration of the grievance. Id. at 182 n.8.

"See notes 26-29 supra and accompanying text.

"The court's dictum stated that "the wrongfully discharged employee may bring an action against his employer in the face of a defense based upon the failure to exhaust contractual remedies. provided that the employee can prove that the union as bargaining agent breached its duty of fair representation. . . . [T The jurisdiction of the courts is no more destroyed by the fact that the employee, as part and parcel of his $\$ 301$ action, finds it necessary to prove an unfair labor practice by the union, than it is by the fact that the suit may involve an unfair labor practice by the employer himself." 386 U.S. at 186.

"See notes 27-29 supra and accompanying text. 


\section{Final Determination Clauses}

A final determination clause purports to bind the grievant, union, and employer to the settlement reached through the grievance procedure set up by the collective bargaining agreement..$^{36}$ Inclusion of such clauses in labor contracts probably reflects a conscious desire of both the union and the employer to restrict the remedies available to grievants in the bargaining unit. The Supreme Court in Republic Steel Corp. v. Maddox ${ }^{37}$ recognized the legitimacy of labor-management interests in delimiting the available remedies. ${ }^{38}$ Thus, employers do not want to handle or defend against groundless claims which can be eliminated by the operation of final determination clauses in collective agreements. ${ }^{.19}$ Union interests are also served since the processing of employee grievances "complements the union's status as the exclusive bargaining representative by permitting it to participate in the continuing administration of the contract" 40 and enhances the union's prestige when it conscientiously and successfully administers grievance claims. ${ }^{41}$ Furthermore, both labor and management have an interest in finalizing the grievance procedure to avoid the uncertainty created by inconsistent judicial interpretations of the collective agreement. ${ }^{42}$ In addition to these private interests, congressional support for enforcing final determination clauses is implicit in section 203(d) of the Taft-Harley Act, ${ }^{33}$ which expresses a desire that the method agreed upon by the parties to collective bargaining agreements be the ultimate means of settling grievances.

Despite a paucity of judicial decisions in which claims have been denied because of the presence of final determination clauses, one may conclude that the courts will not give effect to such a clause unless the parties to the contract clearly provide that the resolution reached by use of the grievance machinery is to be final

\footnotetext{
${ }^{36}$ See note 12 supra and accompanying text.

" 379 U.S. 650 (1965). See notes 26-29 supra and accompanying text.

37379 U.S. at 653.

"See Zile, supra note 26 , at $340-41$.

so 379 U.S. at 653.

"Jd.

'Id. Local 174, Teamsters Union v. Lucas FIour Co., 369 U.S. 95, 103-04 (1962).

"29 U.S.C. $§ 173$ (d) (1964); see notes 14-16 supra and accompanying text.
} 
and binding. ${ }^{4+}$ Perhaps the most edifying judicial expression of this conviction is found in a decision of the Pennsylvania Supreme Court, which asserted: "In order for a contractual remedy to be considered as final and binding, it is our view that the intent of finality must be spelled out therein or at least be contextually implicit from a reading of the agreement." final determination clause is clear, it remains uncertain what actual effect such a clause has on an employee's opportunity to prevail in a section 301(a) action. An examination of cases involving both closed- and open-end grievance procedures is necessary to isolate the determinative factors.

\section{Grievance Procedures With An Arbitration Clause}

It is difficult to ascertain the independent effect of a fina] determination clause in a grievance procedure containing an arbitration clause, for the courts rarely rely on a final determination clause as the sole basis of a decision. Instead, where an arbitration provision is incorporated in the collective bargaining agreement, the courts generally dismiss employees' section $30 \mathrm{I}$ (a) actions on the ground that federal labor policy favors voluntary arbitration as the means of resolving labor disputes. ${ }^{46}$ To promote that policy, the courts refuse to entertain section 301(a) actions filed before completion of the arbitration. ${ }^{47}$ Similarly, if the

\footnotetext{
"See, e.g.. Haynes v. United States Pipe \& Foundry Co., 362 F.2d 414, 416 (5th Cir. 1966); Union News Co. v. Hiddreth, 295 F.2d 658, 660 (6th Cir. 1961); Guille v. Mushroom Transp. Co., 425 Pa. 607, 608, 229 A.2d 903, 904-05 (1967).

"Aughenbaugh v. North Am. Refractories Co., 426 Pa. 211, 217, 231 A.2d 173, 177 (1967).

"See. e.g.. Juhn Wiley \& Sons, Inc. v. Livingston, 376 U.S. 543 (1964); Drake Bakeries, Inc. v. Local 50, American Bakery Workers, 370 U.S. 254 (1962); United Steeiworkers v. Enterprise Wheel \& Car Corp., 363 U.S. 593 (1960); United Steelworkers v. Warrior \& Gulf Nav. Co., 363 U.S. 574 (1960); United Steelworkers v. American Mfg. Co., 363 U.S. 564 (1960); Textile Workers Union v. Lincoln Mills, 353 U.S. 448 (1957).

"See Vaca v. Sipes, 386 U.S. 170, 184 (1966); Republic Steel Corp. v. Maddox, 379 U.S. 650, 657-58 (1965); Smith v. Evening News Ass'n, 371 U.S. 195, 196 n.l (1962).

If the union decides that the employee's grievance lacks merit, it likely will not prosecute the grievance through arbitration. If the collective bargaining agreement contains a final determination clause, the employee thus will not receive an impartial consideration of the merits of his grievance unless he can demonstrate that his bargaining representative has breached its duty of fair representation. See, e.g.. Humphrey v. Moore, 375 U.S. 335 (1964); notes 113-26 infra and accompanying text. Moreover, if the union voluntarily withdraws the grievance during arbitration itself, an employee may be precluded from succeeding in a section 301 (a) action against his employer. Campbell v. Mardigian Corp., 253 F. Supp. 110
} 
employee's claim is grounded on an allegation of the arbitrator's error or unfairness, the refusal to review will be based on a desire to give finality to the arbitration award..$^{48}$ Moreover, by strictly limiting judicial review of arbitration awards, the courts are respecting the expectations of the parties to the labor contract, who feel that the resolution of disputes by an expert impartial arbitrator is superior to other alternatives. ${ }^{49}$

Congressional support for the policy of promoting laborgrievance arbitration may be found in the legislative history of section 203(d), which gives primary emphasis to settlements reached through the collective bargaining process. ${ }^{30}$ The Supreme Court likewise has displayed a deference for arbitration by holding that the arbitrators, not the courts, are to determine whether the procedural prerequisites to arbitration have been satisfied." The

(E.D. Mich. 1966). In both cases, the mere presence of an arbitration provision provides no protection. Indeed these situations are highly similar to that encountered under the open-end procedures, and the same rationale which supports denial of judicial relief where such procedure contains a final determination clause also applies here. See notes 91.98 infra and accompanying text.

${ }^{43}$ E.g., United Steelworkers v. Enterprise Wheel \& Car Corp., 363 U.S. 593 (1960); Miller v. Spector Freight Sys., Inc., 366 F.2d 92 (1st Cir. 1966); Panza v. Armco Steel Corp., 316 F.2d 69 (3d Cir. 1963), cert. denied, 375 U.S. 897 (1964). In Enterprise Wheel, the Court stated that ". . . the question of interpretation of the collective bargaining agreement is a question for the arbitrator. It is the arbitrator's construction which was bargained for; and so far as the arbitrator's decision concerns construction of the contract, the courts have no business overruling him because their interpretation of the contract is different from his." 363 U.S. at 599; see Aaron, Judicial Intervention in Labor Arbitration. 20 STAN. L. Rev. 41 (1967).

2See A. Cox \& D. Bok, Cases and Materials on Labor Law 516-20 (6th ed. 1965); cf. Note, Judicial Review of Labor Arbitration Awards after the Trilog.' 53 CORNell L. REv. 136, 150 (1967); "The fact that collective bargaining agreements almost always contain provisions for arbitration indicates that parties rarely consider not including it. The real reason for an arbitration agreement is practical necessity, not implicit faith in the arbitrator's wisdom."

${ }^{\text {so }}$ S. MIN. ReP. No. 105, PT. 2, 80th Cong., lst Sess. 31 (1947) stated: "Section 203(d) directs the Federal Mediation Service in grievance disputes to emphasize to the parties their obligation to provide in their collective bargaining agreements for the final adjustments of grievances by submitting such disputes to an umpire or adjustment board. Wc thoroughly concur in the desirability of the inclusion in agreements of arbitration as the final step in the adjustment of grievances."

s1 John Wiley \& Sons, Inc. v. Livingston, 376 U.S. 543, $555-59$ (1964), noted in 6 B.C. IND. \& COM. L. REV. 344 (1965), 60 N.Y.U.L. REv. 224 (1965) and 73 YALE L.J. 1459 (1964). In Wiley, the Court chose to leave the question of procedural arbitrability with the arbitrator because it felt that it often would be impossible to determine the procedural issues without examining the substantive questions. The Court also noted that the time expended in getting judicial determinations of procedural issues would vitiate the federal labor policy favoring the rapid resolution of labor-management disputes. 376 U.S. at 556-58. 
NLRB has evidenced a similar attitude..$^{52}$ Both the courts and the NLRB have applied the policy favoring arbitration to bar section 301(a) actions against unions, ${ }^{53}$ employers, ${ }^{54}$ and arbitrators. ${ }^{5 s}$

Given the strong federal support of arbitration and the probable fairness of decisions achieved through a procedure containing an arbitration clause, it is not surprising that courts refuse to review arbitration awards, whether or not there is a final determination clause in the collective bargaining agreement. Even in the absence of an explicit final determination clause, inclusion of an arbitration provision seems to imply that the parties have agreed to a final, binding procedure. ${ }^{56}$ Only if the labor contract contains a specific provision for appellate review of the award ${ }^{57}$ will this inference be refuted. Thus, in litigation involving contracts with arbitration clauses, the presence or absence of a final determination clause will not be crucial unless there is also a specific provision for judicial review of arbitration awards. In this situation the court will be forced to resolve the apparent inconsistency between final determination and judicial review by attempting to discern the intent of the parties in including both provisions. ${ }^{58}$

\footnotetext{
"Since its decision in Spielberg Mfg. Co., 112 N.L.R.B. 1080 (1955), the Board has honored all arbitration awards meeting its tests of fairness and regularity. In Raytheon Company, 140 N.L.R.B. 883 (1963), however, the Board restricted its acceptance to those awards in which the arbitrator had determined the same issue as the one before the Board.

"E.g.. Balowski v. UAW, 372 F.2d 829 (6th Cir. 1967).

"E.g., Miller v. Spector Freight Sys., Inc., 366 F.2d 92 (Ist Cir. 1966); Clover v. Columbus Retail Merchants Delivery, Inc., 115 Ohio App. 467, 185 N.E.2d 658 (1962).

"E.g.. Hill v. Aro Corp., 263 F. Supp. 324 (N.D. Ohio 1967).

${ }^{3}$ Sce, e.g. . Transport Workers, Local 234 v. Philadelphia Transp. Co., 228 F. Supp. 423 (E.D. Pa. 1964); Guille v. Mushroom Transp. Co., 425 Pa. 607, 229 A.2d 903 (1967). The court in Philadelphia Transp. Co., supra at 425, asserted: "There is no provision for appellate review of an arbitration award contained in the collective bargaining agreement between the Union and the P.T.C. Therefore, the Award in issue must be considered a final award."

"See 2 BNa Collective Bargaining - Negotiations and Contracts 51, 301-02 (1966); Smith \& Jones, The Impact of the Emerging Federal Law of Grievance Arbitration on Judges. Arbitrators, and Parties. 52 VA. L. Rev. 831, 897-908 (1966).

Under certain contracts, disputed issues of arbitrability are to be resolved by the courts. For example, a recently-expired collective agreement between the Meter-All Manufacturing Company and the IUE, expressly made arbitration decisions subject to judicial review.

"The presence of both a final determination clause and a provision for judicial review of the arbitration decision might be rationalized by viewing the former as a requirement that the parties adhere to the procedures of the agreement and the latter as the final step in those procedures. The parties would be compelled to carry disputes through the arbitration process, and on review of the arbitration decision could only raise the limited issues of fraud or capriciousness by the arbitrators and arbitrability rather than having available a broader spectrum of attack.
} 


\section{Open-end Grievance Procedures}

Few courts have been compelled to determine the impact of a final determination clause where the grievance procedures are openended, that is, not culminating in arbitration. Nevertheless, in the cases which have arisen, the presence or absence of a final determination clause seems to have made a substantial difference in the outcome of section 301 (a) actions. The leading case on this issue is Haynes $v$. United States Pipe \& Foundry Co. ${ }^{59}$ in which the Court of Appeals for the Fifth Circuit recognized a final determination clause as a bar to a section 301 (a) suit by an employee whose grievance had been prosecuted without resolution through an open-end grievance procedure. The final step of the grievance procedure, which would have required a letter from the international union to the plant manager announcing the union's intention to strike in protest of the plant manager's denial of the employee's claim, was not taken. ${ }^{60}$ Nevertheless, assuming that the employee had exhausted the contractual remedies, ${ }^{6)}$ the court held that under the terms of the contract's final determination clause ${ }^{\text {i2 }}$ the employee's claim was finalized, and therefore judicially barred, by the union's failure to strike. ${ }^{63}$ To support its enforcement of the final determination clause as a defense to the employee's section 301 (a) action, the Haynes court relied upon the Supreme Court's policy of giving full play to whatever means the parties to the

\footnotetext{
99 362 F.2d 414 (5th Cir. 1966), noted in 35 Geo. Wash. L. Rev 590 (1967).

${ }^{\circ 0}$ See 362 F.2d at $415-16$.

bi The court noted: "We may assume arguendo that appellant [employee] has exhausted his contractual remedy. His claim was carried to the point where it would have been necessary for his union to notify the employer of its intention to strikc in support of his claim. At this point, the decision denying him relief was 'final' under the terms of the collective bargaining agreement." Id. at 417 . See note 62 infra.

62 The collective bargaining agreement contained a final determination clause which provided: "Any settlement between the Company and the Union at any step of the above grievance procedure, shall be binding on the Company and the Union and the aggrieved." Id. at 416.

63 "The fact of the matter here is that the union processed appellant's grievance up to the point of striking. The denial of his claim then beeame final. We beleve the law to be that his claim was thereby barred. . . . The action under the terms of the agreement, may be asserted in bar as an affirmative defense." Id. at 418 . The court commented that there was no claim of unfair representation, implying that the employee's claim may not have been barred had there been an allegation of the union's breach of its duty of fair representation in handling the grievance. This would be consistent with the views of other courts on this point. Sce notes 119-26 infra and cases cited therein.
} 
collective bargaining agreement have chosen for settling grievances. ${ }^{64}$ Thus, since the final determination clause constituted an integral element of the grievance procedure, it was immaterial that the agreement had no arbitration provision. ${ }^{65}$

In contrast to Haynes, the collective bargaining agreement under scrutiny in International Brotherhood of Telephone Workers v. New England Telephone and Telegraph Co. ${ }^{66}$ prescribed an openend grievance procedure without any final determination clause. The district court in New England Telphone first determined that it had jurisdiction under section 301 (a) and that both the union and employee had standing to bring the action against the employer, ${ }^{67}$ and then the court considered the merits oi an employee claim which had been processed through all steps of the open-end grievance procedure. ${ }^{68}$ Although no rationale was spelled out to justify the court's inquiry into the merits of the complaint, it was implicit in the court's action that the federal policy of section 203(d) was not powerful enough, in the absence of an explicit final determination clause, to override the rights conferred under section $301(\mathrm{a})$.

Consistent with New England Telphone is the decision of the Court of Appeals of Michigan in Alarcon v. Fabricon Products, Division of Eagle-Picher Co. ${ }^{69}$ Alarcon involved a section 301 (a) suit of a discharged employee whose grievance had been pro-

See notes 14-16 supra and accompanying text.

6s 362 F.2d at 417 .

${ }^{6} 240$ F. Supp. 426 (D. Mass. 1965).

${ }^{67}$ Id. at 428-29. In so ruling, the court relied upon Smith v. Evening News Ass'n, 371 U.S. 195 (1962). See notes 23-25 supra and accompanying text.

In American Motors Corp. v. Wisconsin Employment Relations Bd., 32 Wis. 2d 237, 145 N.W.2d 137 (1966), the Supreme Court of Wisconsin held that where the employer and the union had exhausted the contract's open-end grievance procedure, the union could sue to enforce the collective bargaining agreement against the employer by means of the unfair labor practice procedure of the Wisconsin Employment Relations Board. The court made no mention of a final determination clause. If no such clause was present, the decision is consistent with the theory of the Telephone Workers case. However, if the collective agreement contained such a clause, the court's decision contravenes the federal labor policy by permitting the union to avoid the effect of the final determination clause representing the parties' chosen method of resolving their differences.

68 The court took notice of the fact that the union processed the employee's grievance "through the grievance procedure contained in the collective bargaining agreement without satisfactorily resolving the dispute. The collective bargaining agreement contains no provision for arbitration of unresolved grievances." $240 \mathrm{~F}$. Supp. at 428.

5 Mich. App. 25, 145 N.W.2d 816 (1966). 
cessed through an open-end grievance procedure. After the trial court had granted the employer's motion for summary judgment because the union had agreed to drop the plaintiff's grievance, ${ }^{70}$ the Michigan Court of Appeals reversed and remanded the case for a decision on the merits of the employee's claim, holding that where the collective bargaining agreement "fails to provide a method of resolving ... grievances, any intent of the parties to deny the grieved employee recourse to the courts after exhausting the grievance procedures, must be clearly spelled out."11 Since no type of final determination clause seems to have been present in Alarcon, the decision gives no indication of whether a final determination clause similar to that in Haynes ${ }^{72}$ would be considered sufficiently explicit to deny employees the right to institute a section 301(a) action after exhausting grievance procedure. ${ }^{73}$

Two recent decisions by the Court of Appeals for the Third Circuit suggest a different rationale which casts some doubt on whether, as a general rule, the courts will give conclusive effect to final determination clauses where the collective bargaining agreement fails to provide for impartial arbitration. In Rothlein $v$. Armour \& Co., ${ }^{74}$ the district court which had dismissed an

\footnotetext{
${ }^{70} \mathrm{Id}$. at $\longrightarrow 145$ N.W.2d at 818.

"Id. at 145 N.W.2d at 821 . The court reasoned that the "plaintiffs legal action,
} brought after termination of the grievance process, could not further burden the grievance machinery. Whether or not the union could 'wash out' plaintiff's grievance while it was still only a grievance being processed under the contract, when plaintiffs grievance ripened into a cause of action which he could enforce in the courts, the union had no authority under the contract to destroy the cause of action by agreeing with the company to withdraw the plaintiffs claim." Id. at 145 N.W.2d at 821 (footnotes omitted).

${ }^{72}$ See note 62 supra.

${ }^{73}$ See note 60 supra and accompanying text. The union in Alarcon had voted to strike over all pending grievances, including that of Alarcon, before the settlement between the union and the employer was negotiated, and apparently only the accord prevented the union from striking on behalf of Alarcon and the other grievants. 5 Mich. App. at $\longrightarrow 145$ N.W.2d at 818. This is probably the clearest basis upon which Alarcon may be distinguished from Haynes. See notes 60-63 supra and accompanying text.

Apparently, the Alarcon court considered the employee's eause of action against his employer to be perfected when the union initially decided to strike on his behalf, see id. at 145 N.W.2d at 818 , a decision which created a cause of action that could not be destroyed by any subsequent union action and which excused the employee from having to await the vindication of his contractual rights through the pressure exerted on the employer by the strike.

7391 F.2d 574 (3d Cir. 1968). 
employee's section 301 (a) action on the rationale of Haynes was reversed on a procedural holding." The Third Circuit went further, however, and in strong dictum discussed the factors which it would consider important in deciding whether to accept a private determination of the merits as a basis for granting summary judgment against an employee. ${ }^{76}$ The Third Circuit's approach proposed a particularized inquiry designed in each case to satisfy the court that the dispute was of the type contemplated by the grievance procedures of the contract ${ }^{77}$ and that, despite a coincidence of union and management interests adverse to the interests of the employee, ${ }^{; x}$ the grievance machinery was likely to be impartial.

The Third Circuit had an opportunity to apply its Rothlein rationale in Bieski v. Eastern Automobile Forwarding Co. ${ }^{79}$ The plaintiff employees in Bieski brought their section 301 (a) suit against the employer who had purchased the assets of their former employer's business but had refused to hire them or to allow them

\footnotetext{
'The employee's section 301 suit in Rothlein demanded an accounting and payment allegedly owed under a pension plan set up by a prior collective bargaining agreement. The grievance was pursued unsuccessfully by the employees through the contractual procedures prescribed by the collective bargaining agreement which was in force when the complaint arose. The employer's motion for summary judgment on the basis of this private merit determination was granted by the district court, citing Haynes. 268 F. Supp. at 545. The Court of Appeals for the Third Circuit reversed because a substantial issue of fact remained as to which collective bargaining agreement governed the grievance procedure. This issue was crucial since the prior collective bargaining agreement was also open-end, but contained no final determination clause. 391 F.2d at 576-78.

"See 391 F.2d at 578-80.

"- In Rothlein the court was concerned with whether an action for an "accounting" was the type of "difference" contemplated by the contract. 391 F.2d at 580 . More generally, the court's analysis appears to question whether the subject matter of a particular grievance has been delegated to the grievance procedure by the terms of the contract. Stated in this fashion, the suggested inquiry clearly presages one of the jurisdictional issues in Bieski v. Eastern Auto. Forwarding Co., 396 F.2d 32 (3d Cir. 1968). See notes 84 \& 85 infra and accompanying text.

- Both the employer and the union had a potential economic interest in seeing the employee's claim defeated. The union had secured the employer's promise to contribute directly to its pension fund, rather than maintaining its own separate plan for the employees. This plan might have been jeopardized if the employees were held to have "vested" rights in the prior pension fund. The employer's total liability for pension payments would also probably increase if the grievance was resolved in favor of the employees. The court seemed to consider this situation as creating an intolerable potential for unfairness to the employees. See $391+.2 d$ at 580 n.27.

"396 F.2d 32 (3d Cir. 1968).
} 
to retain their seniority rights as required by the governing multiemployer collective bargaining agreement. The agreement contained a provision for arbitration as well as a final determination clause, ${ }^{80}$ but since the employees' grievance was washed out before an arbitral hearing, the policy preference for arbitration was not a factor in the case. ${ }^{81}$ Pursuing the detailed inquiry espoused by Rothlein, the court found that although the union involved had not breached its duty of fair representation, neither had it provided effective advocacy of the grievants' interests. ${ }^{82}$ In Bieski the unity of union and management interests, which the Rothlein court cited as one reason for disregarding a private-merits determination, was present and strongly influenced the decision to reverse the summary judgment against the employees. ${ }^{83}$ By a somewhat strained interpretation of the collective bargaining agreement, the Bieski court also determined that the Joint Committee's decision to wash out the grievance was "jurisdictional" in the sense that it concerned whether the Committee had the power under the collective bargaining agreement to process the dispute. ${ }^{84}$ At this point an analogy was drawn to the issue of whether or not a particular dispute should go to arbitration, and the court thus justified its inquiry into the merits of the private determination by citing arbitration cases which approved a stricter standard of judicial review. ${ }^{85}$ Although Bieski can be explained on this latter rationale alone, the court's inquiry into the adequacy of the private-grievance machinery was clearly a fundamental part of its analysis. This appears to be the first time a court has approached the question of whether it should give conclusive effect to a private-merits

\footnotetext{
${ }^{20}$ Id. at 34.

"Id. at 36. See note 47 supra.

"Bieski, like Rothlein, presented a fact situation in which arguably the union as wcll as the employer had an interest in seeing the employees' grievance discharged. See note 78 supra. The Bieski union represented the employees of the purchasing and the selling employers. The employees of the purchascr-employer did not want to be pushed down the seniority list by "dovetailing" in the employees of the seller-employer. In the grievance committe the union took a "neutral" position, leaving the committee under the control of the management representatives whose fringe benefit costs were tied to the seniority of his employees. Predictably, the employee grievance was unanimously defeated. 396 F.2d at 36 .

"See id. at 39-40.

uId. at 37-38.

"Id. at 38.
} 
determination by (1) assessing the weight of the employee's claim, (2) measuring the potential for unfairness in the applicable grievance procedure and (3) balancing both (1) and (2) against the collective union, management and employee interest in finalizing their grievance procedure. ${ }^{86}$. Since the finality of each private-merits decision can be tested on these uncertain scales which leave so much room for the courts to apply their own particular view of the merits, the Rothlein-Bieski rationale could introduce much uncertainty into the administration of collective bargaining contracts.

While the paucity of cases construing open-end grievance provisions limits the strength of the conclusions, perhaps some working hypotheses can be constructed as to the effect of final determination clauses in -this context. First, where the collective bargaining agreement contains a final determination clause, but no provision for arbitration, an individual employee whose claim has been finalized will be barred from bringing a section 301(a) action, ${ }^{87}$ unless he can show either that his union has violated its duty of fair representation in representing his interests, ${ }^{88}$ or that the adverse merits determination concerned an issue not delegated to the grievance procedure by the collective bargaining agreement. ${ }^{89}$ However, if the Rothlein-Bieski rationale is followed, another exception will have to be recognized whenever "the adequacy of the proceedings ... [are] not commensurate with the importance of the . . question presented." 90 Second, exhaustion of an open-end grievance procedure will not bar the employee's suit where the section 203(d) policy is not invoked by a clearly expressed final determination clause. ${ }^{11}$ In contrast with the open-end grievance

\footnotetext{
wh This balancing rationale is tied into the controversy over the various theories of the union-management rclationship. See notes $99-112$ infra and accompanying text.

"See Haynes v. United States Pipe \& Foundry Co., 362 F.2d 414 (5th Cir. 1966). See notes 59-63 supra and accompanying text.

"See Vaca v. Sipes, 386 U.S. 171 (1967): Rothlein v. Armour \& Co., 391 F.2d 574, 579 (3d Cir. 1968) (dictum).

"N Rothlein v. Armour \& Co., 391 F.2d 574, 577, $579-80$ (3d Cir. 1968).

* Bieski v. Eastern Auto. Forwarding Co., 396 F.2d 32, 41 (3d Cir. 1968). The Bieski test could be viewed as watering down the Vaca requirement of unfair representation to one of "effective" representation, with the weight of the employee's claim and possible conflicts of interest between the grievant and either his union or other union members as factors in the standard of adequacy.

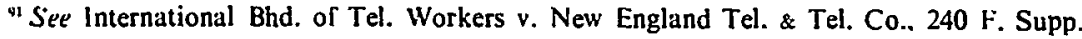


procedure, a section 301(a) suit is generally barred unless the contract specifically provides that the decision of the arbitrator is subject to judicial review. ${ }^{92}$

By granting identical effect to the final determination clause and the arbitration clause on the theory that this is required to give "full play" to section 203(d), the courts perhaps have overlooked several differences between the two. On the one hand, if a contract contains an arbitration clause, either alone or in conjunction with a final determination provision, the individual employee's interest in an impartial determination of the merits of his grievance ${ }^{3.3}$ and the union-management interest in the finality of the settlement achieved under the grievance procedure are served. ${ }^{9 \dagger}$ Therefore, when impartial arbitration is provided for, it seems fair to bar an employee's section 301 (a) action. On the other hand, if the employee's grievance is discharged without an arbitral hearing, not only is the federal labor policy favoring arbitration absent, but also there may be no fully impartial consideration of the merits of the employee's grievance. Thus, an employee may be denied an unbiased determination because of his race, sex, or age; ${ }^{95}$ or because

426 (D. Mass. 1965); Alarcon v. Fabricon Prods., 5 Mich. App. 25, 145 N.W.2d 816 (1966). See notes 66-73 supra and accompanying text.

${ }^{92}$ See note 56 supra and accompanying text.

${ }^{93}$ See notes $46-48$ supra and accompanying text.

${ }^{4}$ See notes 47-54 supra and accompanying text.

9s See. e.g.. Conley v. Gibson, 355 U.S. 41 (1957); Cortez v. Ford Motor Co., 349 Mich. 108, 84 N.W.2d 523 (1957); Wilson v. Hacker, 200 Misc. 124, 101 N.Y.S.2d 461 (Sup. Ct. 1950). Additionally, Title V1l of the Civil Rights Act of 1964, 42 U.S.C. $\S \S 2000 \mathrm{c}-2,-4$ (1964), established the Equal Employment Opportunity Commission to process charges of discrimination based on race, sex, or religion against employers and unions. In Local 12, United Rubber Workers v. NLRB, 368 F.2d 12 (5th Cir. 1966), cert. denied, 389 U.S. 837 (1967), the Fifth Circuit held that a labor organization's breach of its duty of fair representation constitutes an unfair labor practice under the NL.RA so as to give jurisdiction to the NLRB. The court examined the nexus between the Civil Rights Act of 1964 and the NLRA and implied that the Equal Employment Opportunity Commission was not given exclusive jurisdiction over claimed racial discrimination. 368 F.2d at 23-24, noted in 1967 DUKe L.J. 1037; $c f$. Bowe v. Colgate-Palmolive Co., 272 F. Supp. 332, $337-38$ (S.D. Ind. 1967): "The Court finds a fundamental difference between a claim for the violation of a collective bargaining agreement and a claim for the violation of the Civil Rights Act of 1964 . The latter is a statutory embodiment of constitutional rights that all persons are entitled to enjoy, while the former has as its primary purpose the maintenance of industrial peace between labor and management. It is the belief of the Court that an employee has the right to come before the Court and assert his claim under the Civil Rights Act of 1964 without regard to any contractual remedies also available to him." 
he is not a union member, or belongs to a minority faction within the union. ${ }^{96}$ Although an employee is shielded against invidious discrimination by the NLRB and the courts, ${ }^{97}$ he may be unprotected where the union's representation is inadequate, but does not rise to the level of a violation of law.

Further protection for the employee under an open-end grievance procedure may be afforded by the strike vote of the employees, which generally is the final step in such a procedure. The adequacy of this means of "impartial consideration" of the merits of the grievance depends upon the willingness of union members to strike to vindicate the rights of an aggrieved employee in their bargaining unit. Of course, a strike-vote result may be unrelated to the merits of the grievance if the employee is unpopular with his fellow workers, or if the voting employees discern that a strike would be contrary to the national labor policy favoring labor peace, ${ }^{98}$ would be deleterious to the public image of the union, would jeopardize the national security, or would work substantial financial hardship upon them. Despite the possibility that an individual's rights may be inundated by these puissant considerations, there may nevertheless be a real nexus between the strength of the merits of the grievance and the strike vote. Those who vote are employees who may identify with the grievant or may fear similar treatment by the employer in their own cases unless they protest by voting to strike.

Therefore, on balance, it appears that an adequate measure of fairness will be assured the grievant and the union-management interest by according full effect to final determination clauses, regardless of whether or not the contract provides for the arbitration of grievances. Open-end grievance procedures do not deprive employees of all opportunities to be heard on the merits of their claims. They can appeal to their co-employees, and on the basis of invidious discrimination may proceed before the NLRB or the courts against the union for breaches of its duty of fair representation. In the relatively few cases where union and employer interests coincide adversely to the employee, it may be

${ }^{20}$ See, e.g.. Thompson v. Brotherhood of Sleeping Car Porters, 316 F.2d 191 (4th Cir. 1963); Bailer v. Local 470, Teamsters, 400 Pa. 188, 161 A.2d 343 (1960).

"See. e.g., Ford Motor Co. v. Huffman, 345 U.S. 330 (1953).

"See 29 U.S.C. § 141 (b) (1964). 
better to accept the potential for unfairness rather than to embrace the broad exception suggested in Rothlein and Bieski. The courts, therefore, should examine contracts to determine whether they contain final determination clauses, in addition to ascertaining whether there is a provision for impartial arbitration. If either is present, the burden should be on the employee to show special circumstances to prevent entry of summary judgment against him.

\section{THEORIES OF THE UNION-MANAgEMENT RelationshiP}

While various policies support judicial refusal to permit employees to sue under section 301(a) after exhausting the contractual grievance machinery, some jurists and scholars contend that the resulting impairment of individual rights cannot be tolerated. For instance, Mr. Justice Black, dissenting in Vaca v. Sipes," maintained that he was unable "to see how the union's legitimate role as statutory agent is undermined by . . . allowing the injured employee to sue his employer after he has given the union a chance to act on his behalf." ${ }^{100}$ Reaffirming his dissent in Republic Steel Corp. v. Maddox, ${ }^{101}$ Justice Black in Vaca asserted that "an employee should be free to litigate his own lawsuit with his own lawyer in a court before a jury, rather than being forced to entrust his claim to a union . . . ."102 This philosophy, known as the "individual interest predomination" theory, ${ }^{103}$ embraces the view that individual employee interests cannot be protected adequately unless each employee always has an opportunity to obtain judicial or otherwise impartial review of the merits of his grievances against his employer..$^{104}$ It is bottomed upon the notion that the union's

9386 U.S. 171, 203 (1967) (Black, J., dissenting).

$140 / d$. at 209-10.

to1 379 U.S. 650,659 (1965) (Black, J., dissenting).

102386 U.S. at 205 (Black, J., dissenting).

${ }^{103}$ In a 1962 article, Professor Cyrus F. Smythe categorized the three basic schools of thought concerning employee-union conflicts as individual interest predomination, group interest predomination, and joint interest determination. Smythe, Individual and Group linterests In Collective Labor Relations, 13 LAB. L.J. 439 (1962).

"N See Lenholf, The EJfect of Labor Arbitration (Iauses Lipon the Individual. 9 ARB. J. (n.s.) 3 (1954); Murphy, The Duty of Fair Representation Under Taft-Hartley, 30 Mo. L. REv. 373 (1965); Summers, Individual Rights in Collective Agreements and Arbitration, 37 N.Y.U.L. Rev, 362 (1962). Professor William P. Murphy asserted: "The fair representation doctrine can do no more than protect the individual against the bad faith exercise of power. 1 think what the individual needs and what the law should provide, at least in some instances, is an opportunity to have his claimed right under the contract determined on its merits, cven when the union and the employer are acting in admitted good faith." Murphy, supra, at 389. 
duty of fair representation and remedies for its breach cannot sufficiently ensure protection of the interests of individual employees. ${ }^{105}$

In contrast, the Vaca majority found no problem in denying review to grievance settlements under section 301 (a) unless the employee bringing the action could prove that his bargaining representative breached its duty of fair representation. ${ }^{106} \mathrm{Mr}$. Justice Black, in his Vaca dissent, interpreted this view as an expression of the "group interest predomination" theory, which he scored as unjustifiably imposing additional barriers to suits by individual employees against their employers. ${ }^{107}$ The group interest theory embodies the notion that employees receive the best protection for their own individual interests when these are subordinated to their collective interest, as espoused by their elected and exclusive bargaining representative. ${ }^{108}$ Underlying this conclusion is the belief that the rights of individual employees are sufficiently safeguarded by the fiduciary duty of fair representation, which is implemented by granting employees standing to sue to enforce this duty. ${ }^{109}$ If this theory is adopted, as it arguably has been by the Court in Vaca, the interests of employees collectively and individually are best served by strengthening the bargaining representative, an inevitable consequence of the enforcement of final determination clauses. ${ }^{110}$

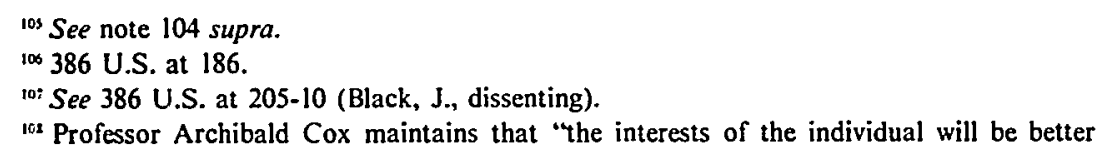
protected on the whole by first according legal recognition to the group interest in the contract administration and then strengthening the representative's awareness of its moral and legal obligation to represent all employees fairly than by excluding the union in favor of an individual cause of action." Cox, Rights Under a Labor Agreement, 69 Harv. L. Rev. 601,657 (1956).

Professor Mozart Ratner argues that "effective protection of employees against the employer requires subordination of individual interests to the collective interest as represented by the exclusive bargaining agent democratically selected by majority rule. To whatever extent individual interest prevails over collective interest, inequality of bargaining power between employer and employee necessarily survives." Ratner, Some Contemporary Observations on Section 301, 52 GEO. L.J. 260-61 (1964).

${ }^{109}$ See Cox, Individual Enforcement of Collective Bargaining Agreements, 8 LAB. L.J. 850, 859 (1957).

110 The limited degree of trust that the individual-interest predomination theory is willing to credit to the union's duty of fair representation constitutes the major difference between the two theories. Thus, while the individual-interest theory questions the efficacy of the protection afforded to the employee by the remedies available for unfair representation, the 
The latest collision of the two interest predomination theories occurred in Rothlein and Bieski, where the Third Circuit embraced "individual interest predomination" in espousing its balancing rationale." These cases, of course, presented the strongest facts on which that theory could operate, for arguably the group interest theory was vitiated by the unity of union and management interest. ${ }^{12}$ To the extent that Vaca was a rejection of the individualinterest-theory analysis, the Rothlein-Bieski rationale would seem to rest upon shaky ground, with only Mr. Justice Black as a possible adherent on the Suprcme Court.

\section{THE DUty of FaIR REPRESENTATION}

The group interest predomination theory, seemingly adopted by the Supreme Court in Vaca, fully recognizes the effective enforcement of the duty of fair representation as an essential element of the theory. However, while the duty of fair representation is implicit in section 9 of the NLRA, as amended by the Taft-Hartley Act, ${ }^{113}$ much uncertainty remains as to how this duty is to be enforced. Initially, an employee's complaint in an unfair representation proceeding must satisfy certain threshold requirements. Thus, it must present more than conclusory statements of fact ${ }^{114}$ and must demonstrate that the union's action or inaction was motivated by bad faith. ${ }^{15}$ For instance, the employee's mere allegation that the union has assumed a position different from his own is not sufficient. ${ }^{16}$ In fact, the Michigan

group-interest theory accepts such remedies as satisfactory and implements them by making an exception to the bar imposed by final determination clauses. See, e.g., Williams v. Wheeling Steel Corp., 266 F. Supp. 651 (N.D.W. Va. 1967); Meola v. Bethlehem Steel Co., 246 Md. 226, 228 A.2d 254 (1967).

"I See text accompanying notes 76-86 supra.

112 See notes 78 \& $82-83$ supra and accompanying text.

${ }^{113}$ Labor Management Relations Act (Taft-Hartley) $§ 9$ (a), 29 U.S.C. \& 159(a) (1964); see Humphrey v. Moore, 375 U.S. 335 (1964); Syres v. Oil Workers Int'l Union, 350 U.S. 892 (1955); Ford Motor Co. v. Huffman, 345 U.S. 330 (1953); Wallace Corp. v. NLRB, 323 U.S. 248 (1944).

"14 See, e.g., Balowski v. UAW, 372 F.2d 829, 835 (6th Cir. 1967); Hardcastle v. Western Greyhound Lines, 303 F.2d 182, 186 (9th Cir.), cert. denied, 371 U.S. 920 (1962); Ostrofsky v. United Steelworkers, 171 F. Supp. 782, $793-94$ (D. Md. 1959), affd, 273 F.2d 614 (4th Cir.), cert. denied, 363 U.S. 849 (1960).

115 See. e.g., Gainey v. Brotherhood of Rwy. Clerks, 313 F.2d 318, 323 (3d Cir. 1963); Hardcastle v. Western Greyhound Lines, 303 F.2d 182, 186 (9th Cir.), cert. denied, 37I U.S. 920 (1962).

${ }^{116}$ Brown v. Truck Drivers Local 395, 264 F. Supp. 776, 778 (D. Md. 1967). The court 
Court of Appeals requires that the complaint "state facts sufficient to raise the presumption that there has been unfair representation."117 The courts, however, have not established rules more specific than these fundamental requirements, which seemingly can be satisfied by a carefully drawn complaint. ${ }^{118}$ Once the issue of union fair representation is properly presented in an employee's section 301(a) action against his employer, the court will inquire into the merits of the claim. Should it find no breach, then under the group interest theory the protection of individual interests is deemed adequate, and judicial review can justifiably be refused if the contract contains a final determination clause. If a breach is found the employee will be permitted review of his contract claim against the employer.

Section 301 (a) itself has been interpreted to provide statutory authorization for judicial inquiry into, and enforcement of, the union's duty of fair representation. Indeed, the evolution of the employee's section 301 (a) right to sue his bargaining representative on the collective bargaining contract where there has been a breach of the duty of fair representation ${ }^{119}$ has paralleled the judicial construction of the section 301 (a) right to sue the employer. Thus, the Supreme Court in Maddox, while requiring the employee to attempt to exhaust his contract remedies, ${ }^{120}$ indicated that the individual employee may seek redress against his union in the courts or by means of an unfair labor practice proceeding if he is not represented fairly. ${ }^{\prime 21}$ More recently, the Vaca Court held that the jurisdiction of the courts to hear an employee's section 301 (a) allegation of unfair representation against the union is not

continued: "As pointed out in Humphrey [375 U.S. 335 (1964)], supra, the plaintiffs must allege that the union had not made an honest effort to serve the interests of all of its members without partiality or hostility toward any segment of its membership." Id.

"' Field v. Local 652, UAW, 6 Mich. App. 140, 148 N.W.2d 552, 555-56 (1967). In the same case, the court stated: "If the employer acted in good faith and in accordance with a union contract's procedure, he should generally be immune from employee suits. $A$ union agreement is assumed to be binding upon the employees and the employer is entitled to assume the union is acting fairly with its members. This general rule facilitates the continuing nature of the bargaining process. It also encourages democracy and union responsibility." $I d$. at $\longrightarrow 148$ N.W.2d at 555.

"'See, e.g., Meola v. Bethlehem Steel Co., 246 Md. 226, 228 A.2d 254 (1967).

"See notes 20-35 supra and cases cited in note 113 supra.

120 See note 29 supra and accompanying text.

"21 "If the union refuses to press or only perfunctorily presses the individual's claim, differences may arise as to the forms of redress then available." 379 U.S. at 652. 
preempted by the NLRB's exclusive jurisdiction of unfair labor practices. ${ }^{122}$ Arguably, this holding reflects the Court's opinion that the General Counsel for the Board will not adequately protect the interests of individual employees. ${ }^{123}$ Where a breach of the duty of fair representation occurs, a final determination clause should not be permitted to bar a section 301 (a) suit either against a union or an employer. ${ }^{124} \mathrm{~A}$ primary purpose of the final determination clause is to protect and advance the position of the bargaining representative. ${ }^{125}$ However, when this representative breaches its fiduciary duty of fair representation, the major premise of group interest predomination is eviscerated. Therefore, the representative should not be able to avail itself of the bar intended to strengthen its representative position when it has itself breached its duty of representation. ${ }^{126}$ Moreover, in such cases the employer should not be permitted to invoke the final determination clause as a bar because there has been no semblance of a true determination of his inculpability. A union's misconduct on an employer's behalf should clearly not be permitted to isolate the employer from his own misdoings.

\footnotetext{
132386 U.S. 171 (1967). See note 32 supra and accompanying text.

13' See note 32 supra.

${ }^{124}$ Even before Vaca. the Fifth Circuit in Haynes, 362 F.2d at 418, noted: "Appellant [plaintiff-employee] does not contend that the union did not faithfully represent him. Sec Humphrey v. Moore, supra, on the duty of the union to do so. He does not charge fraud on the part of either the company or the union. This is a run-of-the-mine case where the grievance procedure was followed and the adverse decision against appellant became final." The implication is that proof of union bad faith would abrogate any employer final determination clause defense to the employee's suit.

${ }^{125}$ See notes 40-41 supra and accompanying text.

12: In Hill v. Aro Corp., 275 F. Supp. 482, 490-91 (N.D. Ohio 1967). the court upheld an arbitration award against an employee's attack, holding that the time for moving to vacate the award had lapsed. Nevertheless, refusing to dismiss the plaintiff-employee's complaint against bis union, the court ruled that the employee "may, if he can prove that the union was arbitrary, discriminatory or not acting in good faith in its representation of plaintiff in the grievance procedure and that some damages flowed from the breach, recover his damages." Id. at 491. The Hill tribunal allowed the employer and the union to be shielded from claims that would have required the court to ignore the arbitration award, which it recognized as final and binding, but thereby permitted a separate cause of action to be maintained against the union. Because the basis of the employee's action was a section 301 (a) clain under both theories, there is no practical distinction between recognizing the existence of a distinct cause of action and merely denying the union the right to assert the arbitrator's award as a bar, at least insofar as the union is concerned. There, however, appears to be a distinction with respect to the employee's action against the employer because the latter, by invoking the award as a bar, ceased to be a party defendant when the court also determined that the employee had not alleged facts sufficient to state an independent cause of action against the employer. Id. at 487-88.
} 


\section{Conclusion}

1t may be generally concluded that the presence of either arbitration provisions or final determination clauses will serve as a bar to section 301(a) actions in the absence of express authorization of judicial review, or a lack of grievance procedure jurisdiction over the issue. It is likewise apparent that under no circumstance should a final determination clause bar a section 301 (a) action where there has been a breach of the duty of fair representation. However, a new problem in the gray area of this scheme was created by the adequacy-of-representation balancing rationale of Rothlein and Bieski. Whether inadequate representation or representation tainted with conflict of interest not reaching the level of unfair representation should also abrogate the final determination bar is an issue with valid considerations on either side. The interest of the employee in effective representation must be weighed against the employer and union interest in obtaining final determinations not conditioned upon judicial scrutiny of so flexible and uncertain a concept as adequacy of representation. In view of the Supreme Court's disposition of Vaca v. Sipes and its preference for the group interest predomination, the vitality of an adequacy-ofrepresentation test remains highly questionable and the threat it poses to final determinations may be short-lived. 
